\title{
Penggunaan Self-Efficacy Terhadap Pengambilan Keputusan Siswa SMP Dalam Penyelesaian Masalah Konseptual
}

\author{
Nita Puspita Sari ${ }^{1}$, Yudi Kurniawan ${ }^{2}$, Risky Muliyani ${ }^{3}$ \\ Program Studi Pendidikan Fisika, STKIP Singkawang, Singkawang, Indonesia \\ nitapuspitasari1617@gmail.com ${ }^{1}$, yudikurniawan1012@gmail.com ${ }^{2}$,kikiriski1012@gmail.com ${ }^{3}$
}

\author{
Kata Kunci : \\ Analisis, self-efficacy, pemahaman \\ konsep, pesawat sederhana
}

\begin{abstract}
ABSTRAK
Terdapat pemahaman konsep yang rendah pada salah satu SMP Negeri di Kota Singkawang, yang ditandai dengan nilai yang jauh dari standar KKN. Penelitian ini bertujuan untuk: 1) untuk menggambarkan penggunaan self-efficacy terhadap pengambilan keputusan siswa SMP dalam menyelesaikan masalah konseptual; 2) untuk menggambarkan korelasi antara self-efficacy terhadap penyelesaian masalah konseptual siswa. Penelitian yang digunakan adalah penelitian deskriptif kualitatif. Subjek pada penelitian ini adalah siswa kelas VIII di salah satu SMP di Kota Singkawang. Teknik yang digunakan dalam pengambilan sampel adalah purposive sampling. Objek dalam penelitian ini adalah self-efficacy dan pemahaman konsep. Hasil penelitian menunjukkan bahwa: 1) bahwa selfefficacy dapat menggambarkan siswa ditandai pada tes kemampuan pemahaman konsep. Implikasi ini dapat dijelaskan dalam beberapa kategori. Kategori self-efficacy yang positif: dua siswa, nilai yang lebih tinggi dan self-efficacy yang lebih tinggi. Kategori self-efficacy yang positif: 1 siswa, nilai yang lebih rendah dan self-efficacy yang lebih rendah. Kategori self-efficacy yang negatif: 1 siswa, nilai lebih rendah tetapi self-efficacy lebih tinggi. Kategori self-efficacy negatif: 3 siswa, nilai lebih tinggi tetapi self-efficacy lebih rendah;2) hubungan antara self-efficacy terhadap pemahaman konsep masuk pada tingkat hubungan yang sangat erat.
\end{abstract}

\section{PENDAHULUAN}

Kurikulum 2013 yang diberlakukan secara bertahap pada pendidikan nasional saat ini menekankan pentingnya keseimbangan kompetensi sikap, pengetahuan dan keterampilan. (Permendikbud, 2013) yang menyebutkan bahwa kualifikasi lulusan yang mencakup sikap, pengetahuan, dan keterampilan siswa harus dipenuhi atau dicapai dari satuan pendidikan pada setiap jenjang pendidikan dasar dan menengah. Proses pembelajaran yang semula terfokus pada pengetahuan, pada kurikulum 2013 ini dilengkapi dengan sikap dan keterampilan melalui proses mengamati, menanya dan mengumpulkan informasi, mengolah informasi dan menginformasikan. (Golamen, 2012) menyebutkan bahwa pendidikan karakter merupakan pendidikan nilai yang mencakup 10 nilai dasar yang saling berkaitan, yaitu: Responsibility (tanggung jawab), Respect (rasa hormat), Fairness (keadilan), Courage (keberanian), Honestly (kejujuran), Citizenship (rasa kebangsaan), Self-disipline (disiplin diri), SelfEfficacy (keyakinan diri), Caring (peduli), Perrseverance (ketekunan). 
Menurut (Bandura, 1998) Self- Efficacy ialah keyakinan seorang individu mengenai kemampuannya dalam mengorganisasi serta menyelesaikan suatu tugas yang diperlukan untuk mencapai hasil tertentu. (Subaidi et al, 2016) Menyatakan self-efficacy adalah keyakinan seseorang terhadap keterampilan serta kemampuan dirinya dalam mengorganisasi dan menyelesaikan permasalahan untuk hasil yang terbaik dalam suatu tugas tertentu. Serta (Ahriani et al, 2016) self-Efficacy adalah keyakinan seseorang terhadap kemampuan yang dimilikinya untuk mengorganisasikan serta bisa menampilkan perilaku performa yang efektif sehingga bisa menyelesaikan tugas tertentu dengan baik. Menurut (Subaidi et al, 2016) Self-efficacy sangat berperan penting dalam segala hal, salah satunya pemahaman konsep.

Self-efficacy siswa sangat penting dalam pemahaman konsep karena akan mempengaruhi keyakinan siswa dalam setiap langkah-langkah penyelesaian masalah yang dilakukan (Utami \& Wutsqa, 2017). Dengan hal ini keyakinan diri (Self-Efficacy) menjadi faktor terpenting dalam pengambilan keputusan. Keputusan (decision) secara harfiah berarti pilihan (choice). Pilihan yang dimaksud di sini adalah pilihan dari dua atau lebih kemungkinan, atau dapat dikatakan pula sebagai keputusan dicapai setelah dilakukan pertimbangan dengan memilih satu kemungkinan pilihan (Anwar, 2014). Sehingga menurut (Steiner, 2010) pengambilan keputusan didefinisikan sebagai suatu proses manusiawi yang didasari dan mencakup baik fenomena individu maupun sosial, didasarkan pada nilai dan fakta, (Steiner, 2010) juga menyimpulkan sebuah pilihan dari antar alternatif dengan maksud bergerak menuju suatu situasi yang diinginkan. Pengambilan keputusan yang tepat akan menghasilkan suatu perubahan baik, namun sebaliknya pengambilan keputusan yang salah akan berdampak buruk (Anwar, 2014). Pengambilan keputusan ini akan berdampak pada pemahaman konsep siswa yang baik maupun kurang baik (Anwar, 2014).

Pemahaman konsep yang kurang baik dapat ditandai dengan tidak memahami makna konten pengetahuan, definisi, dan alasan dari bagian pengetahuan yang saling terkait (Sadiqin et al, 2017). Faktor pemicu rendahnya pemahaman konsep yaitu siswa tidak diberi kesempatan untuk menyelesaikan suatu masalah pembelajaran pada masa lampau. Akibatnya siswa menjadi tidak terbiasa menghubungkan pengetahuan masa lampau dan pengetahuan yang baru didapat. Siswa juga kesulitan dalam memilah pengetahuan yang diperlukan dalam operasi pemecahan masalah pembelajaran. Hasilnya siswa mengalami kesulitan dalam memahami konsep yang sedang diajarkan. Berdasarkan uraian di atas peneliti akan melakukan penelitian dengan judul: "Penggunaan self-efficacy terhadap pengambilan keputusan siswa SMP dalam menyelesaikan masalah konseptual"

\section{METODE}

Metode penelitian ini adalah penelitian deskriptif kualitatif. Penelitian ini dilakukan di salah satu SMP Negeri di Kota Singkawang sebanyak 25 siswa. Instrumen yang digunakan adalah tes pemahaman konsep siswa yang terdiri dari 12 soal pilihan ganda dan skala self-efficacy. Soal tes pemahaman konsep dibuat oleh saya sendiri serta untuk skala self-efficacy saya adopsi dari Nelly (2019).

Pada pelaksanaan penelitian ini dimulai dengan dibagikannya soal tes pemahaman konsep dan skala self-efficacy. Setelah seluruh kegiatan penelitian dilaksanakan maka dilakukan analisis dari data yang telah diperoleh untuk mengetahui sejauh mana tujuan dari penelitian yang dilakukan terjawab.

Dalam penelitian ini, analisis hasil self-efficacy siswa dibagi menjadi dua jenis: self-efficacy positif dan self-efficacy negatif. Self-efficacy yang positif berarti siswa memiliki self-efficacy yang tinggi sehingga ditandai dengan tes pemahaman konsep yang tinggi dan siswa yang memiliki self-efficacy rendah ditandai dengan tes pemahaman konsep yang rendah juga. Sebaliknya, self-efficacy yang negatif menunjukkan bahwa siswa yang memiliki self-efficacy tinggi tetapi tes pemahaman konsepnya rendah dan siswa yang memiliki self-efficacy rendah tetapi tes kemampuan pemahaman konsep yang tinggi juga termasuk kategori self-efficacy negatif. 


\section{HASIL DAN PEMBAHASAN}

Berdasarkan hasil penelitian menunjukkan bahwa dari 25 orang siswa hanya 7 orang siswa masuk kategori self-efficacy positif maupun negatif. Pada kategori self-efficacy yang positif: 2 siswa, nilai yang lebih tinggi dan self-efficacy yang lebih tinggi. Kategori self-efficacy yang positif: 1 siswa, nilai yang lebih rendah dan self-efficacy yang lebih rendah. Kategori self-efficacy yang negatif: 1 siswa, nilai lebih rendah tetapi self-efficacy lebih tinggi. Kategori self-efficacy negatif: 3 siswa, nilai lebih tinggi tetapi self-efficacy lebih rendah.Siswa yang memiliki self-efficacy positif. Serta hasil analisis data penelitian diperoleh koefisien korelasi sebesar 0,9662 .

\section{a. Self-Efficacy Positif}

Siswa yang memiliki self-efficacy yang tinggi akan lebih yakin untuk menunjukan hasil terbaik dan berupaya keras mencapai hasil belajar yang baik (Destiniar et al ,2019). Self-efficacy yang tinggi akan membawa seseorang dalam menentukan tujuan personal yang menantang dan tekun terhadap tujuan ketika menghadapi rintangan. Self-efficacy yang tinggi juga dapat membuat seseorang menggunakan sumber kognitifnya dengan lebih efektif ketika menyelesaikan masalah (Irfan, 2014). Selain itu, orang yang mempunyai self-efficacy tinggi menghadapi rintangan dan ancaman tanpa rasa cemas dan kesedihan (Irfan, 2014).

Dengan demikian dapat disimpulkan bahwa semakin tinggi tingkat self-efficacy siswa maka semakin tinggi pula rata-rata kemampuan pemahaman konsep siswa (Cahyani et al, 2020). Hal ini sejalan dengan penelitian yang dilakukan oleh (Hakasinawati et al, 2017) yang menunjukkan bahwa keyakinan diri (self-efficacy) berpengaruh positif terhadap kemampuan pemahaman konsep.

\section{b. Self-Efficacy Negatif}

Siswa yang memiliki self-efficacy rendah cenderung berprilaku pesimis, rendah diri, mengganggap dirinya bodoh dan selalu mengelak dari tanggung jawab bila diberikan tugas untuk mengerjakan soal, sehingga belajar merupakan beban bagi mereka (Yunianti, 2016).

Menurut (Schunk, 2012) siswa yang memiliki kelemahan dalam belajar menunjukkan interaksi antara self-efficacy dan faktor-faktor lingkungan. Beberapa faktor yang diduga menyebabkan kemampuan pemahaman konsep siswa sangat rendah diantaranya, siswa belum terbiasa menyelesaikan soal non rutin, siswa mudah menyerah dalam menyelesaikan soal, siswa kurang teliti dalam menyelesaikan soal, sehingga keadaan ini berdampak pada hubungan pemahaman konsep dan self-efficacy siswa kelas VIII di salah satu SMP Negeri Kota Singkawang.

\section{KESIMPULAN}

Hasil yang di peroleh dapat disimpulkan bahwa self-efficacy dapat menggambarkan siswa ditandai pada tes kemampuan pemahaman konsep. Implikasi ini dapat dijelaskan dalam beberapa kategori. Kategori self-efficacy yang positif: 2 siswa, nilai yang lebih tinggi dan self-efficacy yang lebih tinggi. Kategori self-efficacy yang positif: 1 siswa, nilai yang lebih rendah dan self-efficacy yang lebih rendah. Kategori self-efficacy yang negatif: 1 siswa, nilai lebih rendah tetapi self-efficacy lebih tinggi. Kategori self-efficacy negatif: 3 siswa, nilai lebih tinggi tetapi self-efficacy lebih rendah dan terdapat hubungan yang signifikan antara self-efficacy terhadap pemahaman konseptual siswa sebesar 0,9662 yang termasuk dalam tingkat hubungan sangat kuat. 


\section{DAFTAR PUSTAKA}

Ahriani et al. (2016). Jurnal Pendidikan Fisika Universitas Muhammadiyah Makassar Studi Analisis Hubungan Antara Self Efficacy dengan Hasil, 4, 223-238.

Anderson, L. W., \& Krathwohl, D. R. (2010). Pembelajaran, pengajaran, dan Asesmen. Pustaka Pelajar. Yogyakarta: Pustaka Belajar.

Anwar, herson. (2014). Proses Pengambilan Keputusan untuk Mengembangkan Mutu Madrasah Herson Anwar, 8(April).

Arikunto, S. (2015). Dasar-dasar Evaluasi Pendidikan. Jakarta: Bumi Aksara.

Bandura, A. (1998). Self-Efficacy, 4(1994), 71-81.

Cahyani et al. (2020). Pengaruh Penerapan Pendekatan Open Ended terhadap Kemampuan Pemahaman Konsep Matematis Berdasarkan Self, 3(2), 125-132.

Destiniar, et al. (2019). DITINJAU DARI SELF EFFICACY SISWA DAN MODEL PEMBELAJARAN THINK PAIR SHARE ( TPS ) DI SMP NEGERI 20 PALEMBANG, 12(1).

Golamen, D. (2012). Eco Literate. San Fransisco: Jossey Bass.

Hakasinawati et al. (2017). Jurnal Pendidikan Matematika Raflesia Vol . 2 No . 2 Tahun 2017 PENGARUH KEYAKINAN DIRI , KEMAMPUAN PEMAHAMAN, 2(2).

Hamdani, et al. (2012). Pengaruh Model Pembelajaran Generatif Dengan Menggunakan Alat Peraga Terhadap Pemahaman Konsep Cahaya Kelas VIII Di SMP Negeri 7 Kota Singkawang. Exacta, $X(1), 79-88$.

Holme et al. (2015). Defining Conceptual Understanding in General Chemistry. Journal of Chemical Education, 92(9), 1477-1483.

Irfan, M. (2014). HUBUNGAN SELF-EFFICACY DENGAN PENYESUAIAN DIRI TERHADAP PERGURUAN TINGGI PADA MAHASISWA BARU FAKULTAS PSIKOLOGI UNIVERSITAS AIRLANGGA, 3(3), 172-178.

Koontz. (2010). Manejemen, terj. Yim Dosen Fakultas Ekonomi Universitas Indonesia. Jakarta: Erlangga.

Mayasari, D. et al. (2019). Physics Achievement Test Implies S tudents' Self-Efficacy on Decision Making Process, 4(2), 64-69.

Permendikbud. Standart Isi Pendidikan Dasar dan Menengah (2013).

Ridwan. (2012). Skala Pengukuran Variabel-Variabel Penelitian. Bandung: ALFABETA, cv.

Sadiqin et al. (2017). Pemahaman konsep IPA siswa SMP melalui pembelajaran problem solving pada topik perubahan benda-benda di sekitar kita. Jurnal Inovasi Pendidikan IPA, 3(1), 52.

Schunk, D. (2012). Teori-teori pembelajaran: perspektif pendidikan. (Translate by Eva Hamdiah dan Rahmat Fajar).

Steiner, A. G. (2010). Kebijakan Strategi Manajemen, terj. Tim Dosen Fakultas Ekonomi Universitas Indonesia. Jakarta: Erlangga.

Subaidi et al. (2016). Self-efficacy siswa dalam pemecahan masalah matematika, 144-145.

Sugiyono. (2014). Metode Penelitian Pendidikan Pendekatan Kuantitatif, Kualitatif, dan R\&D. Bandung: ALFABETA, cv.

Uno \& Koni. (2013). Assessment Pembelajaran. Jakarta: Bumi Aksara.

Utami, R. W., \& Wutsqa, D. U. (2017). Analisis Kemampuan Pemecahan Masalah Matematika dan 
Self-Efficacy Siswa SMP Negeri di Kabupaten Ciamis An Analysis of Mathematics Problemsolving Ability and Self-Efficacy Students of Junior High School in Ciamis Regency, 4(2), 166-175.

warsito, hadi. (2009). PEDAGOGI | Jurnal Ilmiah Ilmu Pendidikan Volume IX No.1 April 2009 29, IX(1), 29-47.

Widiadnyana I, W. et al. (2014). Pengaruh Model Discovery Learning Terhadap Pemahaman Konsep IPA dan Sikap Ilmiah Siswa SMP. E-Journal Program Pascasarjana Universitas Pendidikan Ganesha Program Studi IPA, 4(2), 1-13.

Yunianti, E. (2016). PENGARUH MODEL PEMBELAJARAN DAN SELF-EFFICACY TERHADAP HASIL BELAJAR MATEMATIKA SISWA SMA NEGERI 1 PARIGI, 8-19. 